\title{
Využití epidemiologie odpadních vod pro sledování spotřeby nelegálních drog a dalších látek v českém a mezinárodním kontextu
}

\section{VĚRA OČENÁŠKOVÁ}

Klíčová slova: epidemiologie odpadních vod - nezákonné drogy - LC-MS/MS - marihuana - extáze - metamfetamin amfetamin - kokain - efedrin - tramadol

\section{SOUHRN}

Příspěvek přináší stručnou souhrnnou informaci o projektu Stanovení množství nelegálních drog a jejich metabolitů v komunálních odpadních vodách nástroj pro doplnění údajů o spotřebě drog v České republice (identifikační číslo projektu VG 20122015101) se zkráceným názvem DRAGON a o mezinárodní konferenci $2^{\text {nd }}$ International Conference on „Wastewater-based drug epidemiology“, která se konala ve dnech 11.-15. 10. 2015 ve švýcarské Asconě.

\section{ÚVOD}

Přestože slovo droga má více významů, většinou se všem vybaví spojení s něčím nezákonným. Užívání nelegálních drog je celospolečensky nežádoucí záležitost, hledají se cesty k omezení jejich spotřeby. Tato spotřeba se obvykle monitoruje prostřednictvím dotazníkových akcí, údaji zjištěnými při policejní práci - kriminální činy spojené s požitím nebo získáváním drog a údaji ze zdravotnictví - choroby vzniklé na základě zneužívání drog.

Jako doplňková metoda se $v$ současnosti využívá analýza komunálních odpadních vod - epidemiologie odpadních vod (WBE - wastewater-based epidemiology). Epidemiologii odpadních vod byl položen základ na přelomu let 1999 až 2000 [1] a poprvé byla aplikována v povodí řeky Pád [2]. Od dob svého vzniku se stala plnohodnotnou rozvíjející se disciplínou, která spojuje práci expertů z mnoha oborů.

Zpočátku byla epidemiologie odpadních vod využívána především pro sledování nezákonných látek (drog), léčiv atd. v odpadních vodách, a tím ke zjištování stavu spotřeby drog, případně léčiv ve sledovaných lokalitách, především městských aglomeracích. $V$ dnešní době je tento způsob sledování spotřeby drog v dané lokalitě využíván na celém světě. Zároveň však dochází k rozšiřování spektra sledovaných látek o další markery, které umožňují zjistit další informace o populaci - zdravotní stav, spotřebu alkoholu atd.

O tom, jak rozšiřený obor epidemiologie odpadních vod je, svědčila i $2^{\text {nd }}$ International Conference on "Wastewater-based drug epidemiology", která se konala ve dnech 11.-15. 10. 2015 ve švýcarské Asconě.

$\checkmark$ první části tohoto príspěvku je prezentován projekt DRAGON realizovaný v letech 2012 až 2015 ve VúV TGM, v. v. i., druhá část je věnována výše zmíněné konferenci.

\section{PROJEKT DRAGON}

V České republice byl epidemiologický přístup ke sledování spotřeby drog aplikován v projektu Stanovení množství nelegálních drog a jejich metabolitů v komunálních odpadních vodách - nástroj pro doplnění údajů o spotřebě drog v České republice (identifikační číslo projektu VG 20122015101) se zkráceným názvem DRAGON. Tento projekt byl řešen v rámci Programu bezpečnostního výzkumu České republiky v letech 2010-2015 (BII/2 - VS) a byl financovaný formou dotace z rozpočtové kapitoly Ministerstva vnitra České republiky. Cílem projektu bylo zavést vhodnou analytickou metodu pro měření koncentrací vybraných látek v komunálních odpadních vodách, pomocí této metody analyzovat odebrané vzorky a zpětnou kalkulací spočítat látkové odnosy u jednotlivých drog. Součástí projektu byla i Sociodemografická studie včetně analýz prostorového rozložení obyvatelstva a identifikace rizikových skupin uživatelů návykových látek (drog). Tuto studii zpracovala společnost Accendo - Centrum pro vědu a výzkum, o. p. s., se sídlem v Ostravě [3].

Řešitelský tým prošel během řešení projektu mnoha změnami, klíčovými osobami byli Věra Očenášková, Petr Tušil, Alena Svobodová, Danica Pospíchalová a Petra Kolářová.

Hlavním výstupem projektu byla Metodika aplikace epidemiologie odpadních vod pro stanovení odnosu nezákonných látek (drog) v České republice (http://www.vuv.cz/files/pdf/220/221_certifikovana_metodika_pro_stanoveni_odnosu_drog_stanoveni_def.pdf).

Původní počet aglomerací zapojených do projektu (deset) se díky výborné spolupráci s místními čistírnami odpadních vod postupně podařilo rozširíit na dvacet pět, jejich lokalizace je znázorněna na obr. 1. V jednotlivých městech proběhly sedmidenní, v Ostravě pak 14denní odběrové kampaně, při kterých byly odebírány 24hodinové slévané vzorky. Každý rok byly kampaně realizovány ve čtyřech termínech, a to v dubnu, červnu, záŕí a listopadu. V Praze, Brně, Ostravě, Ústí nad Labem, Plzni, Frýdku-Místku, Orlové, Haviŕově, Karviné a Českém Těšíně probíhal monitoring dva roky (celkem tedy 8 odběrových kampaní), v ostatních lokalitách byl jejich počet nižší. Hlavní odběrová místa byla na přitoku na čistírnu odpadních vod po hrubém předčištění. Tam, kde to umožnovala stoková sít, byla další odběrová místa situována i v uzlových bodech stokové sítě. Př́klad z Brna je na obr.2. 


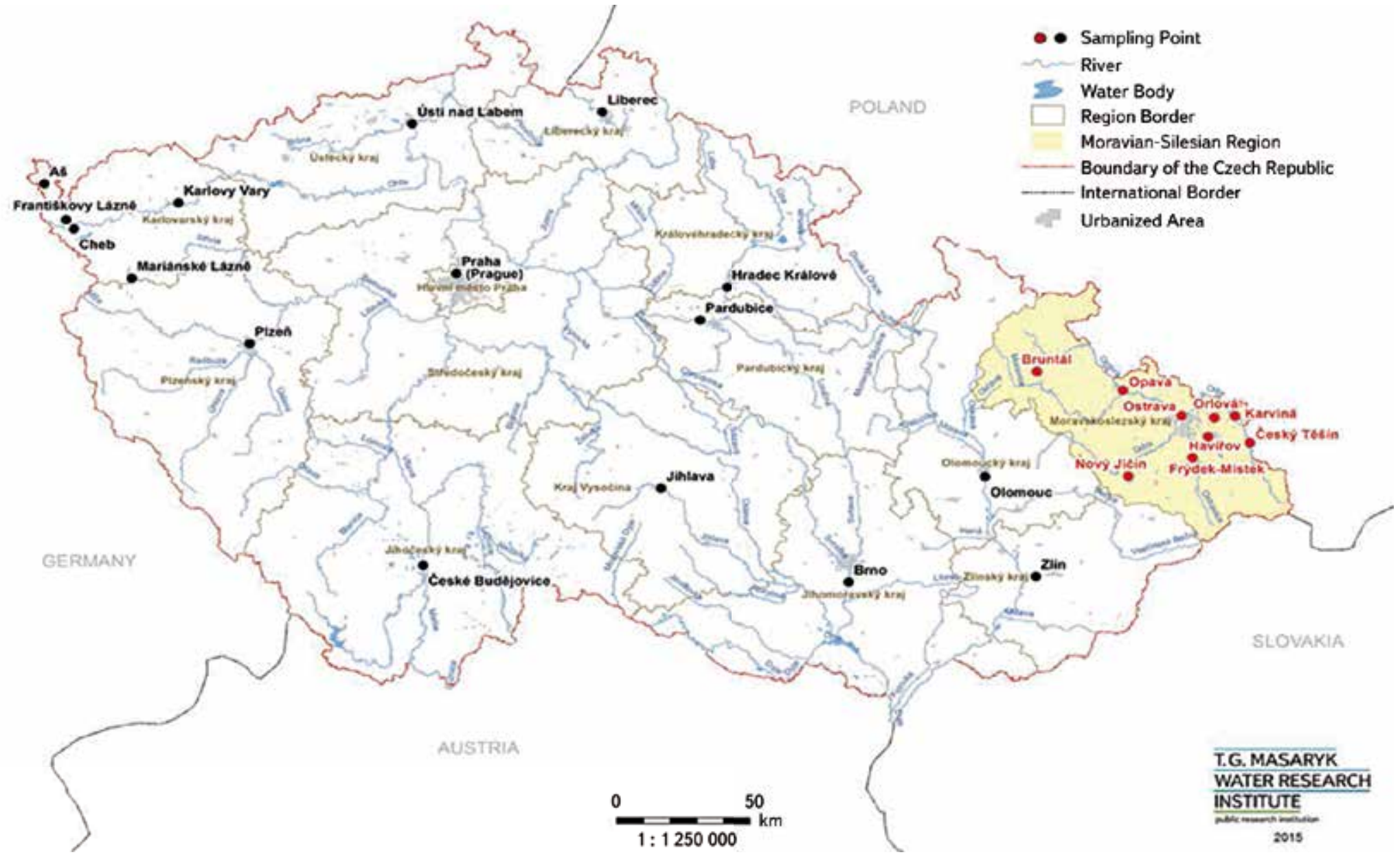

Obr. 1. Lokalizace sledovaných čistíren odpadních vod v České republice

Fig. 1. Localization of monitored WWTP in the Czech Republic

Odebrané vzorky odpadních vody byly analyzovány metodou on-line SPE LC-MS/MS po ionizaci elektrosprejem v pozitivním nebo negativním modu [4].

Ve vzorcích odpadních vod byly sledovány původní drogy a z důvodu jejich preměny $v$ organizmu i jejich významné metabolity, které jsou také vylučovány do odpadních vod. Ke zpětné kalkulaci se u některých drog vychází právě z těchto metabolitů a nikoliv z látek původních. Sledovány byly tyto sloučeniny:

- amfetaminy (metamfetamin (pervitin), amfetamin, 3,4-methylen-dioxy-N-methylamfetamin (MDMA, extáze));

- kokain a jeho metabolity benzoylekgonin a kokaethylen;

- opioidy (heroin, morfin, metabolit 6-acetylmorfin);

- LSD;

- buprenorfin;

- metadon a jeho hlavní metabolit EDDP;

— efedrin a pseudoefedrin;

- tramadol;

- THC-COOH (hlavní metabolit marihuany).

Vedle nelegálních drog byly sledovány i látky používané pro substituční léčbu metadon a buprenorfin, prekurzory využívané pro výrobu drog (efedrin a pseudoefedrin) a účinná látka léčiv předepisovaných na bolesti opioid tramadol, který je často zneužíván [5].

\section{VÝSLEDKY PROJEKTU A POROVNÁNÍ S EVROPOU}

Celkem bylo v průběhu projektu odebráno a zanalyzováno více než 2500 vzorků odpadních vod, ve všech vzorcích byly nezákonné drogy, jejich metabolity a další sledované látky nalezeny. Koncentrace jednotlivých analytů (ng/l) byla zpětnou kalkulací prepočtena na mg/den/1000 obyvatel [6]. Díky tomuto přepočtu Ize mezi sebou porovnávat jednotlivé sledované lokality.

Kromě porovnání jednotlivých sledovaných lokalit v rámci České republiky bylo provedeno také srovnání s evropskou studií realizovanou v letech 2011-2013 [7].

Extáze (MDMA) je typickou „party“ drogou. Její spotřeba výrazně stoupá o víkendech a hudebních akcích. V České republice byla nejvyšší spotřeba této drogy v Praze, následovalo Brno, Plzeň a Ostrava. Po dobu konání hudebního festivalu Summer City Fest v Plzni a festivalu Colours of Ostrava stoupla spotřeba extáze proti průměru $v$ uvedených městech až šestkrát. Ve srovnání s Evropou se Česká republika pohybuje na evropském průměru.

Nejvyšší spotřeba kokainu, jehož užívání má také víkendový charakter, byla opět v Praze, dále potom v Plzni, Ústí nad Labem a v Brně. V mnoha evropských městech je spotřeba několikanásobně vyšší, Česká republika se pohybuje těsně pod průměrem.

Spotřeba metamfetaminu (pervitinu) v České republice je naopak několikanásobně vyšší než v Evropě. Na prvním místě v České republice je Ústí nad Labem. Některé zjištěné koncentrace byly extrémně vysoké, a byly ze statistického hodnocení vyloučeny. Protože ve stejných vzorcích byly naměřeny i velmi vysoké 


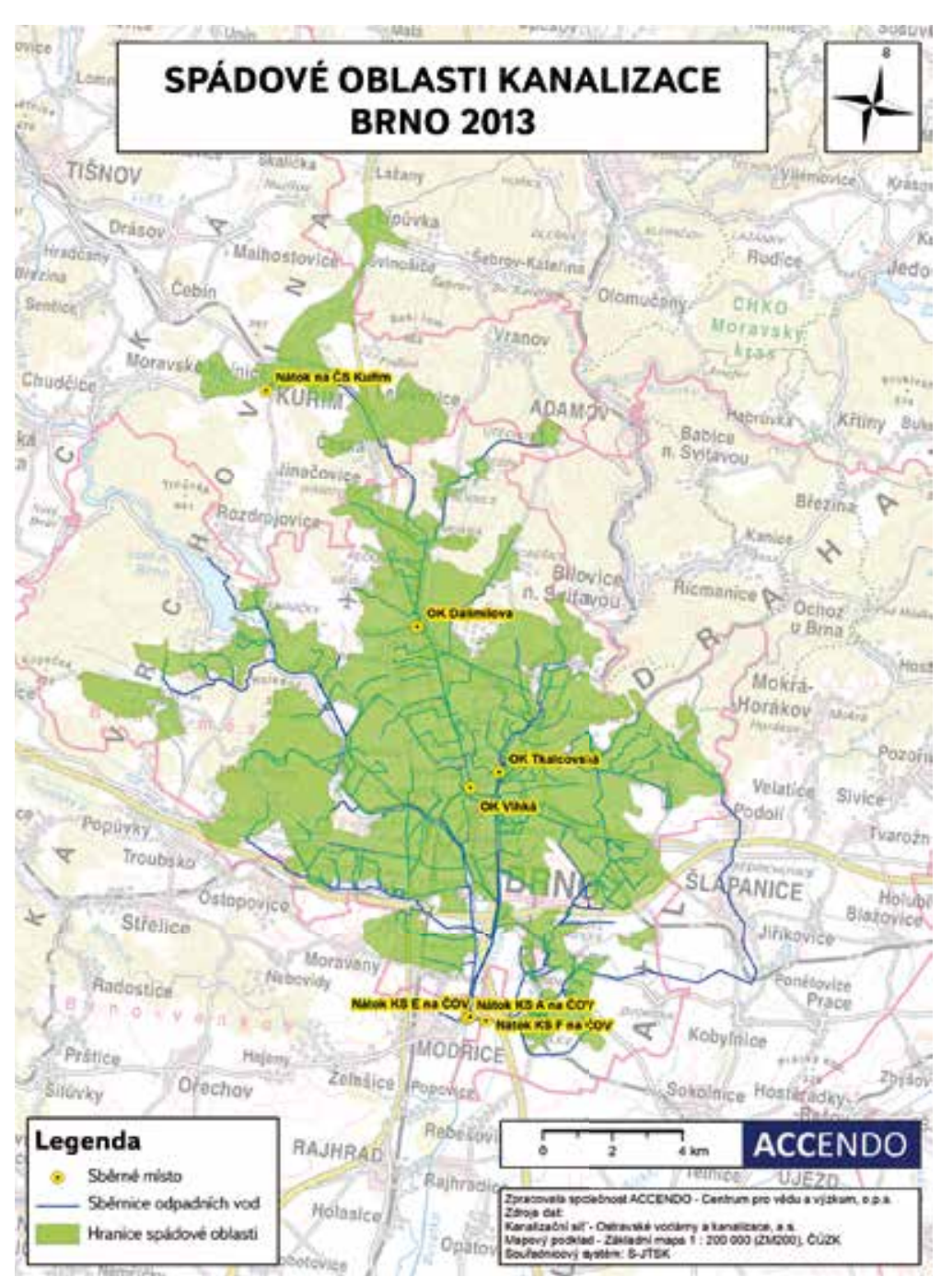

Obr. 2. Spádové oblasti a odběrová místa na kanalizační síti města Brno

Fig. 2. Catchment areas and sampling places of Brno sewerage system

koncentrace efedrinu, který slouží k výrobě této drogy, a nálezy byly v lokalitách, ve kterých Ize předpokládat výskyt nezákonných varen pervitinu, je nanejvýš pravděpodobné, že došlo ke kontaminaci odpadních vod právě z těchto varen. Dalšími městy s vysokou spotřebou metamfetaminu jsou Plzeň, Praha a Ostrava.

Rovněž spotřeba marihuany je v České republice vysoká. Pořadí českých měst podle její spotřeby je Praha, Plzeň, Ostrava a Brno. Srovnání s Evropou nebylo možné, protože nebylo žrejmé, jakým způsobem byla provedena zpětná kalkulace. Ve studii, s kterou byly výsledky porovnávány [7], nebyl uveden použitý prepočítávací faktor.

Na rozdíl od Evropy je v České republice relativně nízká spotřeba amfetaminu - nejvyšší nálezy jsou príbližně 15x nižší než nejvyšší nálezy v Evropě Pořadí v ČR je Ústí nad Labem, Praha, Ostrava a Plzeň.

Tramadol je účinná látka rady léků předepisovaných na bolest (Tramal, Mabron, Noax). Řadí se mezi opioidy a může na něj vzniknout závislost. Často je také zneužíván. Jeho spotřeba o víkendech narůstá až třikrát.

Detailněji jsou výsledky uvedeny ve sborníku z konference Hydrochémia 2016 [8].

Průběžné výsledky projektu byly prezentovány také na několika mezinárodních konferencích, zejména pak na konferenci v Asconě.

\section{MEZINÁRODNÍ KONFERENCE WASTEWATER-BASSED DRUG EPIDEMIOLOGY, 10.-15. 10. ASCONA, ŠVÝCARSKO}

Konference se zúčastnilo 80 expertů z 23 zemí ze čtyř světadílů. Bylo předneseno 44 ústních prezentací, v plakátové sekci bylo prezentováno 18 posterů, 9 z nich bylo představeno formou bleskové prezentace. Ústní príspěvky byly rozděleny do osmi sekcí. Českou republiku zastupovaly tři příspěvky autorů z VúV TGM, v. v. i. (jedna přednáška (Očenášková), dvě plakátová sdělení (Tušil, Kvičalová)).

Přednášky v sekci Monitoring informovaly o využití epidemiologického prístupu k monitorování spotřeby nezákonných látek. Bezesporu jednou z nejvýznamnějších byla prezentace Kevina Thomase. Informoval o výsledcích celoevropské studie, která probíhala v letech 2011 až 2015 celkem ve 42 evropských zemích. Z této studie jasně vyplývá, že je nanejvýš vhodné doplnit stávající metody zjištování spotřeby drog analýzou odpadních vod [7]. Dalšími zajímavými príspěvky přinášejícími informace z mimoevropského prostředí byly prezentace Xiqing Li z Číny a Cobuse Gerbera z Jižní Austrálie. Jak v Číně, tak v Jižní Austrálii je převládající drogou metamfetamin. $\vee$ Evropě dominuje metamfetamin jen v některých oblastech - severské země, část Německa (Sasko), Česká republika.

Odběry odpadní vody jsou realizovány většinou na přítoku na čistírnu. V sekci Transformace byly príspěvky zabývající se chováním jednotlivých látek při průtoku kanalizačním systémem. Napríklad v príspěvku Ann-Kathrin McCall (Swiss Federal Institute of Aquatic Science and Technology) bylo řešeno rozdílné chování jednotlivých látek v př́tomnosti či nepř́tomnosti biofilmu. Například benzoylekgonin (metabolit kokainu) a MDMA (extáze) se za určitých podmínek $\checkmark$ prítomnosti biofilmu transformují. Tato transformace obecně může mít vliv na přesnost zpětného výpočtu spotřeby nezákonných drog.

Při zpětné kalkulaci je velmi důležitý korekční faktor, který vyjadřuje poměr molekulárních hmotností zvolené drogy a specifické látky (metabolitu nebo nezměněné drogy) násobený průměrnou procentuální metabolizací drogy na zvolený metabolit, popř. původní drogu, prochází-li droga organismem částečně nezměněna. Emma Gracia-Lor z italského Instituto di Ricerche Farmacologiche "Mario Negri" představila studii, na jejímž základě navrhuje upřesnění korekčních faktorů pro zpětný výpočet spotřeby drog. Pro porovnání spotřeby drog v jednotlivých lokalitách je velmi důležité používat stejný korekční faktor.

Rychle se vyvíjející prístrojová technika umožňuje analyzovat látky ve stále nižších koncentracích, s lepším rozlišením jednotlivých látek, presnější identifikací. V sekcích Analytika/NPS (nové psychoaktivní substance), Enanciometrické profilování a Alkohol/festivaly/NPS byly zajímavé příspěvky z této oblasti.

Přednáška Wayna Halla z University of Qeensland, Centre for Youth Substance Abuse Research z Austrálie uvedla sekci, která se zabývala řešením etických a legálních problémů spojených s využitím monitoringu spotřeby drog prostřednictvím analýzy odpadních vod. Při využití tohoto postupu v malých lokalitách (zábavní centra, školy, vězeňská zařízení) je nutné prezentaci výsledků věnovat zvláštní pozornost, aby nedošlo např. k nevhodné interpretaci prostřednictvím médii.

Sledování způsobu užívání drog se věnovala ve své studii Lisa Benaglia (Ecole des Sciences Criminelles, University of Lausanne, Švýcarsko). V průběhu trvání týdenního hudebního festivalu byly odebírány vzorky tak, aby byly zachyceny rozdíly $v$ aplikaci drog $v$ průběhu jednoho festivalového dne i celého festivalu. Spotřeba kokainu, marihuany a metamfetaminu $v$ průběhu celého festivalu mírně stoupala, ale byla stejná jako průměrná spotřeba ve Švýcarsku, spotřeba extáze (MDMA) a amfetaminu byla v průběhu festivalu několikanásobně vyšší. Během jednoho dne prủběžně stoupala spotřeba extáze (MDMA), zatímco kokain byl pravděpodobně konzumován před začátkem festivalového dne.

Několik dalších přednášek bylo věnováno využití epidemiologického přístupu ke sledování konzumace alkoholu a nikotinu. 
Novému směřování využití epidemiologického prístupu byla věnována poslední sekce Nové metody, další látky. Prostřednictvím sledování různých biomarkerů a specifických metabolitů v odpadních vodách je a bude možno sledovat zdravotní stav populace.

Konference byla velmi zajímavá a prínosná a je zřejmé, že epidemiologie odpadních vod se bude i nadále rozvíjet.

Další možnosti využití epidemiologického prístupu k analýze odpadních vod jasně definuje Kasprzyk-Hordern. Komunální odpadní vody obsahují komplexní směs chemických látek včetně humánních metabolitů - biomarkerů. Kvantitativní měření těchto specifických látek poskytne informaci např. o způsobu stravování, zdravotním stavu, výskytu chorob, spotřebě alkoholu, léčiv či expozici populace environmentálním a potravinovým kontaminantům [9].

\section{ZÁVĚR}

Projekt Stanovení množství nelegálních drog a jejich metabolitů v komunálních odpadních vodách - nástroj pro doplnění údajů o spotřebě drog v České republice splnil svůj účel a přinesl údaje o spotřebě nezákonných drog a dalších látek v 25 městech České republiky. Celkově v těchto městech žije více než třetina obyvatel Česka. Byla certifikována metodika, která je plně kompatibilní s postupy používanými v Evropě i v dalších mimoevropských lokalitách.

Modifikace metodiky pro malé lokality byla a je již využívána ve spolupráci s policií České republiky především v Moravskoslezském kraji. V některých školách v tomto kraji byly ve stejném časovém úseku provedeny dotazníkové akce, slinné testy na přitomnost drog a odběry a analýza př́slušných odpadních vod. Ukázala se významná shoda mezi slinnými testy a rozbory odpadních vod. Epidemiologický prístup k analýze odpadních vod má velký potenciál a bylo by přinosné, kdyby tento přístup byl i nadále aplikován, rozvíjen a využíván jak ve Vúv TGM, v. v. i., tak v rámci České republiky.

\section{Poděkování}

V̌̌echny odebrané vzorky byly zpracovány v Referenčnílaboratoři složek životního prostředía odpadü VúV TGM, v. v. i.

Projekt by nebylo možno realizovat bez úzké spolupráce s následujicími kličovými institucemi a subjekty v oblasti vodovodů a kanalizaci: Pražské vodovody a kanalizace, a. s., Vodárna Plzeň, Ostravské vodárny a kanalizace, a. s., Severočeské vodovody a kanalizace, a. s., Brněnské vodárny a kanalizace, a. s., VEOLIA Voda Česká republika, a. s., Severomoravské vodovody a kanalizace, a. s., CHEVAK Cheb, a. s., Moravská vodárenská, a. s., Severočeská vodárenská společnost, a. s., Vodárny a kanalizace Karlovy Vary, a. s., ČEVAK, a.s.

\section{Literatura}

[1] DAUGHTON, C.G. Illicit drugs: contaminants in the environment and utility in forensic epidemiology. Rev.Environ. contam. toxicology. 2001, (210), p. 59-110.

[2] ZUCCATO, E CHIABRANDO, CH CASTIGLIONI, S, CALAMARI, D et al Cocaine in surface waters: a new evidence-based tool to monitor. Environmental Health: A Global Access Science Source, 2005, 4(14), p. 1-7. doi: 10.1186/1476-069X-4-14. ISSN 1476069x. Dostupné také z: http://www.ehjournal.net/ content/4/1/14

[3] HRUŠKA, L., HRUŠKOVÁ, A., DOLEŽALOVÁ, H. aj. Sociodemografická studie včetně analýz prostorového rozloženi obyvatelstva a identifikace rizikových skupin uživatelů návykových látek (drog). Ostrava, 2012.

[4] POSPÍCHALOVÁ, D., OČENÁŠKOVÁ, V., SVOBODOVÁ, A. a KOLÁŘOVÁ, P. Metoda stanovení nelegálních drog a jejich metabolitů v odpadních vodách. In. HUCKO Pavel. Zborník prednášokzo XLI. ročníka konferencie s medzinárodnou účastou "Nové analytické metody v chémii vody" Hydrochémia 2014. Bratislava: Slovenská vodohospodárská spol'očnost', 2014, s. 35-44. ISBN 978-80-89062-97-3.

[5] NECHANSKÁ, B., MRAVČÍK, V. a POPOV, P. Zneužívánípsychoaktivních lékư vČeskérepublice: identifikace a analýza zdrojů dat. 1. vyd. Praha: Úřad vlády České republiky, c2012. Monografie (Úřad vlády České republiky). ISBN 978-80-7440-073-5.
[6] OČENÁŠKOVÁ V TUŠIL, P, POSPÍCHALOVÁ, D, SVOBODOVÁ, A a KOLÁŘOVÁ, P. Nezákonné drogy $\checkmark$ odpadních vodách. Vodohospodárský spravodajca: dvojmesačník pre vodné hospodárstvo a životné prostredie. 2014,57, s. $7-8$

[7] THOMAS, K.V., BIJLSMA, L., CASTIGLIONI, S., et al. Comparing illicit drug use in 19 European cities through sewage analysis. Science of The Total Environment. 2012, 432, p. 432-439. DOI: 10.1016/j. scitotenv2012 06 069 ISSN 00489697. Dostupné také z: http://linkinghub elsevier.com/retrieve/pii/ S0048969712008959

[8] OČENÁŠKOVÁ, V., TUŠIL, P., POSPÍCHALOVÁ, D., SVOBODOVÁ, A. a KOLÁŘOVÁ, P. Co o nás (a drogách) vypovídají odpadní vody. In: HUCKO, Pavel. Zborník prednášok zo XLII. ročníka konferencie s medzinárodnou účastou "Nové analytické metódy v chémii vody" Hydrochémia 2016. Bratislava: DALI-BB, s. r. o., Banská Bystrica, 2016, s. 109-120. ISBN 978-80-89740-10-9.

[9] KASPRZYK-HORDERN, B., BIJLSMA, L., CASTIGLIONI, S., et. al. Wastewater-based epidemiology for public health monitoring. Water and Sewerage Journal, 4, p. 25-26.

\section{Autor}

Ing. Věra Očenášková

凶vera_ocenaskova@vuv.cz

Výzkumný ústav vodohospodářský T. G. Masaryka, v. v. i.

Příspěvek prošel lektorským řízením.

\section{USE OF WASTEWATER-BASED EPIDEMIOLOGY FOR MONITORING OF ILLICIT DRUGS CONSUMPTION IN CZECH AND INTERNATIONAL CONTEXT \\ OCENASKOVA, $\mathrm{V}$.}

TGM Water Research Institute, p. r. i.

Keywords: wastewater-based epidemiology - illicit drugs LC-MS/MS - marihuana - ecstasy - methamphetamine amphetamine - cocaine - ephedrine - tramadol

This paper presents a brief summary of information about the project Determination of the amount of illicit drugs and their metabolites in municipal wastewater - new tool for obtaining of complementary data on illicit drug consumption in the Czech Republic and about the $2^{\text {nd }}$ International Conference on "Wastewater-based drug epidemiology", which was held from 11.-15. 10. 2015 in Ascona, Switzerland. 